\title{
Airborne ultra-wideband radar sounding over the shear margins and along flow lines at the onset region of the Northeast Greenland Ice Stream
}

\author{
Steven Franke ${ }^{1}$, Daniela Jansen ${ }^{1}$, Tobias Binder ${ }^{1, *}, J$ John D. Paden ${ }^{2}$, Nils Dörr ${ }^{3}$, Tamara A. Gerber ${ }^{4}$, \\ Heinrich Miller ${ }^{1}$, Dorthe Dahl-Jensen ${ }^{4}$, Veit Helm ${ }^{1}$, Daniel Steinhage ${ }^{1}$, Ilka Weikusat ${ }^{1,5}$, \\ Frank Wilhelms ${ }^{1,6}$, and Olaf Eisen ${ }^{1,7}$ \\ ${ }^{1}$ Alfred Wegener Institute, Helmholz Centre for Polar and Marine Sciences, Bremerhaven, Germany \\ ${ }^{2}$ Centre for Remote Sensing of Ice Sheets (CReSIS), University of Kansas, Lawrence, KS, USA \\ ${ }^{3}$ Institute of Photogrammetry and Remote Sensing, Karlsruhe Institute of Technology, Karlsruhe, Germany \\ ${ }^{4}$ Physics of Ice, Climate, and Earth, Niels Bohr Institute, University of Copenhagen, Denmark \\ ${ }^{5}$ Department of Geosciences, Eberhard Karls University Tübingen, Germany \\ ${ }^{6}$ Department of Crystallography, Geoscience Centre, University of Göttingen, Germany \\ ${ }^{7}$ Department of Geosciences, University of Bremen, Bremen, Germany \\ *now at Ibeo Automotive Systems, Hamburg, Germany
}

Correspondence: Olaf Eisen (olaf.eisen@awi.de) and Daniela Jansen (daniela.jansen@awi.de)

\begin{abstract}
We present a high-resolution airborne radar data set (EGRIP-NOR-2018) for the onset region of the Northeast Greenland Ice Stream (NEGIS). The radar data were acquired in May 2018 with Alfred Wegener Institute's multichannel ultra-wideband (UWB) radar mounted on the Polar6 aircraft. Radar profiles cover an area of $\sim 24000 \mathrm{~km}^{2}$ and extend over the well-defined shear margins of the NEGIS. The survey area is centred at the location of the drill site of the East Greenland Ice-Core Project (EastGRIP) and several radar lines intersect at this location. The survey layout was designed to: (i) map the stratigraphic signature of the shear margins with radar profiles aligned perpendicular to ice flow, (ii) trace the radar stratigraphy along several flow lines and (iii) provide spatial coverage of ice thickness and basal properties. While we are able to resolve radar reflections in the deep stratigraphy, we can not fully resolve the steeply inclined reflections at the tightly folded shear margins in the lower part of the ice column. The NEGIS is causing the most significant discrepancies between numerically modelled and observed ice surface velocities. Given the high likelihood of future climate and ocean warming, this extensive data set of new high-resolution radar data in combination with the EastGRIP ice core will be a key contribution to understand the past and future dynamics of the NEGIS. The EGRIP-NOR-2018 radar data products can be obtained at the PANGAEA Data Publisher (https://doi.pangaea.de/10.1594/PANGAEA.928569; Franke et al. 2021a).
\end{abstract}


https://doi.org/10.5194/essd-2021-91

Preprint. Discussion started: 6 April 2021

(c) Author(s) 2021. CC BY 4.0 License.

\section{Introduction}

The Northeast Greenland Ice Stream (NEGIS) efficiently drains a large area of the Greenland Ice Sheet and is a crucial component of the ice sheet mass balance (Fahnestock et al., 1993; Rignot and Mouginot, 2012). It extends from the central ice divide over more than $600 \mathrm{~km}$ towards the northeastern coast, where it discharges ice through the three marine-terminating glaciers (79 N Glacier, Zachariae Isbræ and Storstrømmen Glacier). The currently prevailing hypothesis is that an anomaly of elevated geothermal heat flux (GHF) leads to extensive basal melting (Fahnestock et al., 2001) and induces ice flow. The GHF at the onset of NEGIS is the most important and, at the same time, most uncertain parameter in the representation of basal melt and the subglacial hydrology in ice flow models (Smith-Johnsen et al., 2020). However, the large gap between observed and modelled basal melt rates (Gerber et al., 2021; Zeising and Humbert, 2021; MacGregor et al., 2016; Buchardt and Dahl-Jensen, 2007) inside the ice stream and in the broader surrounding of the NEGIS onset, raise questions about the real thermal state at the bed. The exceptionally high GHF proposed by Fahnestock et al. (2001) would be non-compatible with known geological processes (Jóhannesson et al., 2020; Blackwell and Richards, 2004). Therefore, Bons et al. (2020) raise the question of how fast flow at the NEGIS onset is possible without an extraordinary high basal heat flux and meltrates.

Unlike other ice streams in Greenland, the NEGIS lacks an extensive overdeepened bed, and thus lateral topographic constraints (Joughin et al., 2001; Franke et al., 2020). The ice stream more or less symmetrically broadens along flow, as more ice is dragged through the shear margins (Fahnestock et al., 2001; Joughin et al., 2001). Subglacial water routing in combination with subglacial till deformation seems to be a further controlling mechanism of ice flow at the onset of the NEGIS (Keisling et al., 2014; Christianson et al., 2014). The outlet area is characterised by an overdeepened basin covered with unconsolidated sediments (Joughin et al., 2001; Bamber et al., 2013). Ice thinning as a consequence of increasing oceanic water temperatures around Greenland, could thus potentially be transmitted far upstream (Christianson et al., 2014), and changes in the hydropotential might have significant effects on the ice stream geometry. The high susceptibility of NEGIS to marine-triggered discharge and the expected increase in ocean water temperatures in the years to come (Yin et al., 2011; Straneo et al., 2012) raises questions about the future ice stream stability and its effect on the Greenland Ice Sheet mass balance.

Large scale ice flow models are essential tools to predict the future behaviour of glaciers and ice sheets and are necessary to estimate future sea-level rise. Until today, these models fail to successfully simulate the NEGIS due to insufficient understanding of the key processes responsible for ice flow dynamics (Mottram et al., 2019; Shepherd et al., 2020), limiting the prediction accuracy. The East Greenland Ice-Core project (EastGRIP; https://eastgrip.org) aims to drill a deep ice core in the upstream area of the NEGIS, providing valuable insights into the climate record, basal properties and ice flow history at the drill site. Ice cores provide in situ information on physical and chemical properties at high resolution but are limited as being a spatial point measurement. Hence, further geophysical techniques are required to extrapolate this information to obtain a complete picture of the ice dynamic properties.

Radio-echo sounding (RES) has long become a standard method in glaciology. The polar ice sheets as well as low-latitude glaciers and ice caps have extensively been covered by airborne (e.g. Steinhage et al., 1999; Schroeder et al., 2020) or groundbased (e.g. Pälli et al., 2002) RES surveys. The transmitted electromagnetic waves are sensitive to changes in dielectric per- 
https://doi.org/10.5194/essd-2021-91

Preprint. Discussion started: 6 April 2021

(c) Author(s) 2021. CC BY 4.0 License.

(c) (i)

mittivity and electrical conductivity and get reflected, scattered or refracted at interfaces of dielectric contrasts in the medium they propagate (Fujita et al., 1999). The most common glaciological application is the sounding of ice thickness and bedrock topography (e.g. Hempel and Thyssen, 1992; Dahl-Jensen et al., 1997; Steinhage et al., 1999; Nixdorf and Göktas, 2001; Kanagaratnam et al., 2001). Reflections within the ice column, or so-called internal reflection horizons (IRH), are often caused by impurity layers of volcanic origin representing isochronous horizons (Millar, 1981). These provide valuable information on the ice flow regime and strain history (Vaughan et al., 1999; Jacobel et al., 1993; Hodgkins et al., 2000) and can be used to reconstruct past accumulation rates (e.g. Richardson et al., 1997; Nereson et al., 2000; Siegert and Hodgkins, 2000; Pälli et al., 2002; Nereson and Raymond, 2001), to match ice cores from different locations (e.g. Jacobel and Hodge, 1995; Siegert et al., 1998; Hempel et al., 2000) and to validate numerical ice flow models (e.g. Huybrechts et al., 2000; Baldwin et al., 2003). Further applications of RES include the detection of crevasses (e.g. Zamora et al., 2007; Eder et al., 2008; Williams et al., 2014), mapping of subglacial lakes and basal hydrology (e.g. Carter et al., 2007; Palmer et al., 2013; Young et al., 2016), identifying thermal regimes (e.g. Murray et al., 2000; Copland and Sharp, 2001), determining snow and firn genesis (e.g. Frezzotti et al., 2002) and obtaining information on the crystal orientation fabric (e.g. Matsuoka et al., 2003; Eisen et al., 2007; Jordan et al., 2020).

We present unique airborne radar data of the onset region of NEGIS recorded in 2018 by a multichannel ultra-wideband radar system. The data set consists of profiles oriented parallel and perpendicular to the ice flow direction. The high alongtrack and range resolution allows consistent isochrone tracing, providing insights into the three-dimensional structure of the ice stream. In combination with the EastGRIP ice core, this dataset contributes to a better understanding of ice flow dynamics of the NEGIS. In our manuscript, we introduce the study site and survey design. Furthermore, we describe the radar data processing and the respective data products. The data are freely available at the PANGAEA data publisher (https://doi.pangaea. de/10.1594/PANGAEA.928569).

\section{Survey region and previous work}

In May 2018, we recorded radar data in the vicinity of the drill site of the EastGRIP ice core. An area of $\sim 24,000 \mathrm{~km}^{2}$ was mapped with $7494 \mathrm{~km}$ of radar profiles along flow lines and perpendicular to ice flow (Figure 1). The survey region extends $\sim 150 \mathrm{~km}$ upstream and downstream of the EastGRIP drill site and ranges from the central part of the ice stream up to $50 \mathrm{~km}$ beyond the shear margins. In our survey region, the ice stream accelerates from $\sim 10$ to more than $80 \mathrm{~m} \mathrm{a}^{-1}$ and widens from $\sim 15$ to $\sim 55 \mathrm{~km}$. The radar data also covers the transition in the position of the shear margin as well as strongly folded internal stratigraphy outside of the ice stream (see Figure 1). Figure $1 \mathrm{~b}$ and $\mathrm{c}$ show the locations of radar profiles in relation to the ice surface velocity. Profiles extending perpendicular to ice flow have a spacing of $5 \mathrm{~km}$ in the region close to the drill site and $10 \mathrm{~km}$ further up- and downstream. Along-flow profiles either follow flowlines, which in some cases pass through the shear margins, or are constantly located inside the ice stream. Other profiles are oriented parallel to ice flow of the NEGIS but are located outside of the ice stream. 
https://doi.org/10.5194/essd-2021-91

Preprint. Discussion started: 6 April 2021

(c) Author(s) 2021. CC BY 4.0 License.

(c) (i)

The ice thickness in our survey region ranges from $2059 \mathrm{~m}$ to $3092 \mathrm{~m}$ and shows, on average, a gradual decrease in thickness from the upstream to the downstream part (Franke et al., 2020, 2019). An analysis of the bed topography, basal roughness and bed return echoes by Franke et al. (2021b) shows that our survey area can be divided into two different morphological regimes. The upstream part (upstream of EastGRIP) is characterised by a narrow ice stream width with accelerating ice flow velocity, a smooth bed with elongated flow-parallel subglacial landforms and a soft till layer at the base (Christianson et al., 2014). Downstream of EastGRIP, the ice stream widens, and we note an overall change to a rougher and more variable bed geomorphology. The ice stream widens up to $57 \mathrm{~km}$ and ice flow velocity keeps constant and decreases locally (Franke et al., 2021b).

In the 2012 summer field season, a scientific consortium collected ground-based geophysical data (RES and seismic survey) as well as a shallow ice core (Vallelonga et al., 2014). Christianson et al. (2014) examined the ice-bed interface by means of radar and seismic data analysis. They found high-porosity, water-saturated till, which lubricates the ice stream base and most likely facilitates ice stream flow. Keisling et al. (2014) used the same radar data to analyse the internal radar stratigraphy and suggest that the basal hydrology controls the upstream portion of the NEGIS. By contrast, the downstream part is rather confined by the bed topography. Riverman et al. (2019a) and Riverman et al. (2019b) analysed the shear margins in particular and observed an increased accumulation and enhanced firn densification in the upper ice column as well as wet elongated subglacial landforms at the bed. Furthermore Holschuh et al. (2019) use RES data to evaluate 3-D thermomechanical models of the NEGIS. The authors highlight the complexity of the stagnant to streaming ice flow transition and provide insights into the englacial heat transport. Finally, a comprehensive chemical analysis of a $67 \mathrm{~m}$ deep firn core was conducted by Vallelonga et al. (2014). The results demonstrated that a deep ice core at this location has the potential to retrieve a reliable record of the Holocene and last-glacial cycle.

\section{Methods}

\subsection{Radar data acquisition}

The ultra-wideband (UWB) airborne radar is a Multichannel Coherent Radar Depth Sounder (MCoRDS, version 5) which was developed at the centre for Remote Sensing of Ice Sheets (CReSIS) at the University of Kansas (Hale et al., 2016). It has an improved hardware design compared to predecessor radar depth sounders by CReSIS (Gogineni et al., 1998; Wang et al., 2015). The radar configuration deployed in 2018 consists of an eight-element radar array mounted under the Polar 6 Basler BT-67 aircraft's fuselage. The eight antenna elements function as transmit and receive channels using a transmit-receive switch. The total transmit power is $6 \mathrm{~kW}$, the radar can be operated within the frequency band of $150-600 \mathrm{MHz}$. The pulse repetition frequency (PRF) is $10 \mathrm{kHz}$, and the sampling frequency is $1.6 \mathrm{GHz}$. The characteristics of the transmitted waveform as well as the recording settings can be manually adjusted. We refer to the combined transmission/reception settings as waveforms in the following.

All profiles were recorded using linear frequency-modulated chirps in the frequency band of $180-210 \mathrm{MHz}$, antenna elements oriented with the E-plane aligned with the along-track ( $\mathrm{HH}$ polarisation), and the transmit antenna beam pointed toward nadir. 

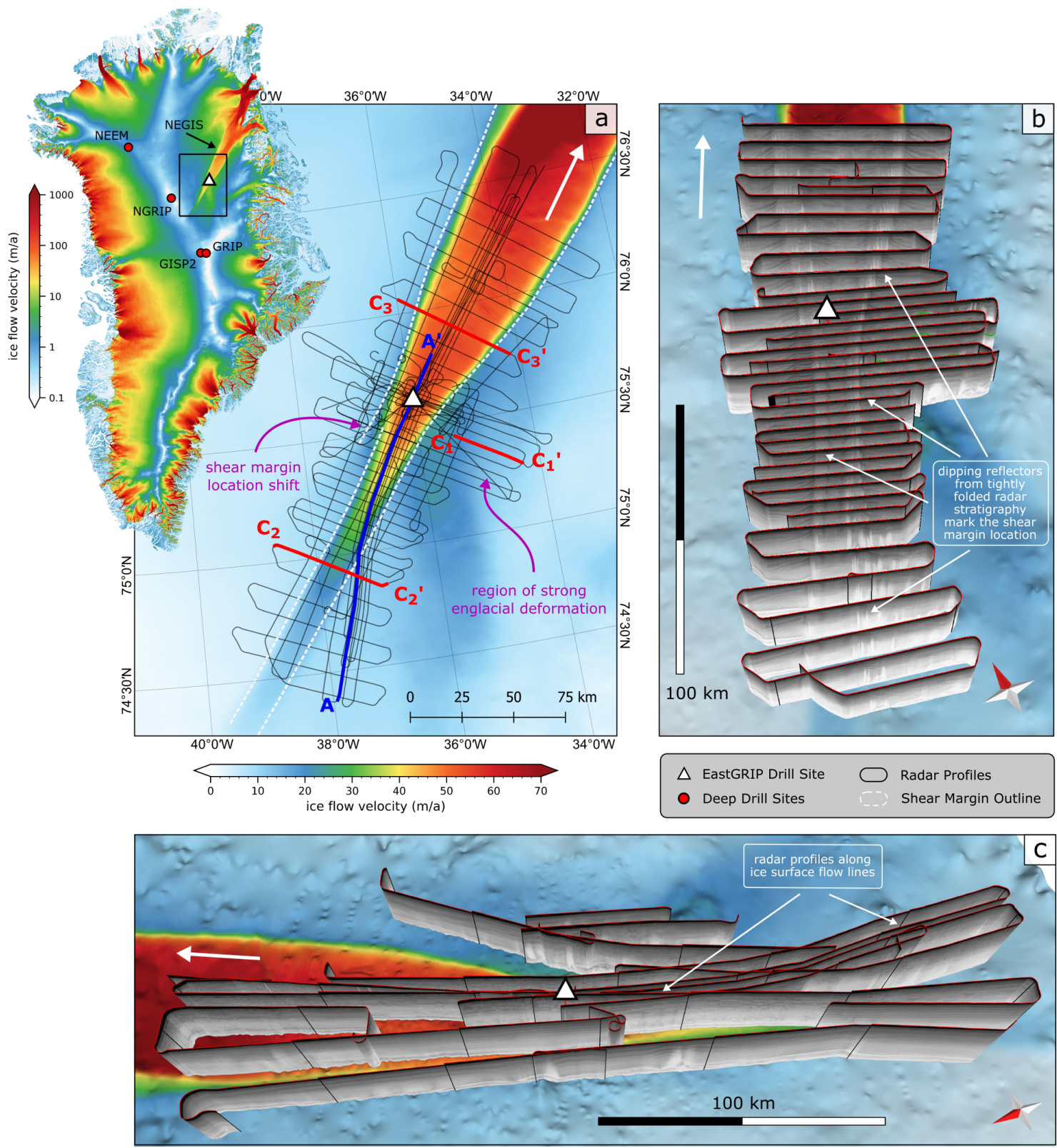

Figure 1. Location of the EGRPI-NOR-2018 survey area in Northeast Greenland with the MEaSUREs ice surface velocity from Joughin et al. (2017) in the background. (a) The radar survey lines are centred at the EastGRIP drill site (white triangle) and extend up to $150 \mathrm{~km}$ upstream and downstream of the NEGIS. The locations of one along-flow radar section (Figure 2; blue) and three cross-flow radar sections (Figure 3; red) are shown in panel (a). The ice flow direction of the ice stream is indicated with a white arrow. 3D images of the cross-flow profiles and along-flow profiles are shown in (b) and (c), respectively. The radar sections are shown with a vertical exaggeration factor of $z$ $=10$. The ice surface velocity (Joughin et al., 2017) is shown on a logarithmic scale (log10) for entire Greenland (upper left image) and on a linear scale for panels (a), (b) and (c). For panel (b) and (c) the ice surface velocity is projected on top of the bed topography model from Franke et al. (2020). The projection for all maps is: WGS 84 / NSIDC Sea Ice Polar Stereographic North (EPSG:3413). 
Table 1. Acquisition parameters of the EGRIP-NOR-2018 radar campaign.

\begin{tabular}{lc}
\hline Parameter & Value \\
\hline Radar system & MCoRDS5 \\
Frequency range & $180-210 \mathrm{MHz}$ \\
Waveform signal & $1 \mu \mathrm{s}, 3 \mu \mathrm{s}, 10 \mu \mathrm{s} \mathrm{chirp}$ \\
Waveform presums ${ }^{a}$ & $2,4,32$ \\
Pulse Repetition Frequency & $10 \mathrm{kHz}$ \\
Sampling frequency & $1600 \mathrm{MHz}$ \\
Tukey window taper ratio & 0.08 \\
Transmit channels & 8 \\
Receiving channels & 8 \\
Aircraft altitude above ground & $\sim 360 \mathrm{~m}^{-1}$ \\
Aircraft velocity & $260 \mathrm{~km} \mathrm{~h}^{-1}$ \\
\hline \multicolumn{2}{c}{${ }^{2}$ Presums are set for each waveform individually. }
\end{tabular}

We used three alternating waveforms to increase the dynamic range of the system (see Table 1). Short pulses $(1 \mu \mathrm{s})$ and low receiver gain of $11 \mathrm{~dB}$ to image the glacier surface, and longer pulses (3-10 $\mu \mathrm{s})$ with higher receiver gain $(48 \mathrm{~dB})$ to image internal features and the ice base. Recorded traces were coherently presummed with zero-pi modulation in the hardware (Allen et al., 2005) to reduce the data rate and to increase signal-to-noise ratio (SNR), leading to a reduced effective PRF. The presum factors were selected with regard to the pulse length of the respective waveform. To reduce range sidelobes without losing much signal power, the transmitted and the pulse compression filter were amplitude-tapered using a Tukey window with a taper ratio of 0.08 (Li et al., 2013).

Before the data acquisition, the amplitude, phase and time delay of the antenna elements were equalized during a test flight over open water during the transit to Greenland. During data acquisition, the position of the aircraft was determined by four NovAtel DL-V3 GPS receivers, which are sampling at $20 \mathrm{~Hz}$. The GPS system operates with dual-frequency tracking so that the position accuracy can be enhanced during post-processing.

\subsection{Radar data processing}

The acquired data comprised 24 total radargrams, one from each pairwise combination of 8 receivers and 3 waveforms. The post-flight processing goal was to create single radargrams of the profiles covering the ice sheet from surface to bed with high SNR, fine resolution and high dynamic range. The main processing included pulse compression in the range dimension, synthetic aperture radar focusing in the along-track dimension and array processing in the cross-track/elevation-angle dimension. Lastly, we vertically concatenated the radargrams of the three waveforms. The post-processing tools are implemented in the CReSIS Toolbox (CReSIS, 2020b). 
At first, the recorded traces were pulse compressed using a Tukey time domain weighting on the pulse and frequency domain matched filtering with a Hanning window to reduce sidelobes. For this purpose, the matched filter duplicates the transmitted waveforms based on the radar transmit settings.

SAR processing was carried out to focus the SAR radargrams in the along-track direction. The SAR processing is based on the fk-migration technique for layered media (Gazdag, 1978), which was adapted for radioglaciology (Leuschen et al., 2000). We used a two-layered velocity model with constant permittivity values for air $\left(\epsilon_{r}=1\right)$ and ice $\left(\epsilon_{r}=3.15\right)$. The air-ice interface was tracked using quicklook imagery, which is generated using 20 coherent averages followed by five incoherent averages by an automated threshold tracker. Platform motion compensation is applied during averaging. The SAR aperture length at each pixel was chosen to create a fixed along-track resolution of $2.5 \mathrm{~m}$. A requirement for the fk-migration is a uniformly sampled linear trajectory of the receivers along the SAR aperture extent. Changes in aircraft elevation, roll, pitch and heading lead to phase errors in the migrated data, thus to decreased SNR and blurring. Processed GPS and INS data in high precision from the aircraft were used to correct these effects. The motion compensation consisted of (1) uniform resampling the data in along-track using a windowed sinc interpolation, (2) fitting lines to the resampled trajectory with the length of the SAR aperture and (3) correcting any flight path deviations from the straight lines with phase shifts in the frequency domain.

After the along-track focusing, the channels were combined to increase the SNR and reduce the impact of surface clutter and off-nadir reflections. The delay-and-sum method allows for steering the antenna array beam. The antenna array beam is steered toward nadir by coherently summing the data from each channel while accounting for the actual position of each measurement phase centre. Eleven along-track averages (multilooking) are then performed to reduce speckle in the imagery.

Finally, the different waveform images were vertically combined to increase the dynamic range of the result. The TWT at which the radargrams are combined were chosen with regard to the pulse durations of the transmitted waveforms and the surface return in order to avoid saturation of the high gain channels due to the strong surface return. For 3 waveform collection with $1 \mu \mathrm{s}, 3 \mu \mathrm{s}, 10 \mu \mathrm{s}$ nadir waveforms, image 2 is combined with image 1 after $3 \mathrm{e}-6 \mathrm{~s}$ after the surface reflection and image 3 with image $210 \mathrm{e}-6 \mathrm{~s}$ after the surface return (see Figure 5).

\subsection{Resolution and uncertainty analysis}

\subsubsection{Range resolution}

The theoretical range resolution after pulse compression is

$\delta r=\frac{k c}{2 B \sqrt{\epsilon_{r}}}$,

where $c$ denotes the speed-of-light in a vacuum, $\epsilon_{r}$ the real part of the ordinary relative permittivity, $B$ the bandwidth of the transmitted chirp and $k$ the windowing factor due to the frequency and time domain windows. For the bandwidth of $30 \mathrm{MHz}$, the theoretical range resolution in ice with $\epsilon_{r}=3.15$ and $k=1.53$ is $4.31 \mathrm{~m}$. 
In addition, to estimate the accuracy of a specific target (internal layer or bed return), we have to consider the RMS error of the dielectric constant (CReSIS, 2020a). Here we depend on the exact detection of the ice surface reflection, which is well constrained for our data.

To determine range resolution variability for the bed reflection for the radar data, we performed a crossover analysis of bed pick intersections (see Franke et al., 2020) and calculated the mean deviation $h_{c}$. We consider an error on the order of $1 \%$ for the dielectric constant for typical dry ice (Bohleber et al., 2012),

$\sigma_{r}=\sqrt{\left(h_{c}\right)^{2}+\left(\frac{T}{2} 0.01\right)^{2}}$,

with the ice thickness $T$ and a mean value for crossover deviation, $h_{c}$. The full analysis of the range resolution of the bed reflection is documented in Franke et al. (2020) and shows a variability from 13 to $17 \mathrm{~m}$.

\subsubsection{Bed return resolution}

A further parameter is the size of the area illuminated by the radar wave in the bed reflection signal. Here we consider a crosstrack resolution for a typical rough surface $\sigma_{y}$. It is constrained by the pulse-limited footprint and depends on the Tukey and Hanning window parameters,

$175 \sigma_{y}=2 \sqrt{\frac{\frac{H}{\sqrt{\varepsilon_{r}}} c k_{i}}{B}}$,

where $H$ is the elevation of the aircraft over the ice surface. All EGRIP-NOR-2018 flights were performed at an aircraft elevation of $\sim 365 \mathrm{~m}$ above ground. When off-nadir clutter is visible in the radargrams, the cross-track resolution depends on the full beam width, $\beta_{y}$, of the antenna array,

$\beta_{y}=\arcsin \frac{\lambda_{c}}{N d_{y}}$,

where $\lambda_{c}$ is the wavelength at the centre frequency, $N$ is the number of array elements and $d_{y}$ the element spacing of the antennas. The cross-track resolution is now defined as

$\sigma_{y}=2 \frac{H+T}{\sqrt{\varepsilon}} \tan \frac{\beta_{y} k_{t}}{2}$.

For areas without signal-layover, the cross-track footprint ranges between 300-350 $\mathrm{m}$ for an ice column of 2000-3000 $\mathrm{m}$ in our survey region (Franke et al., 2020). Where layover occurs, we have to consider Equation (5) with a beam angle of $\sim 21^{\circ}$. Here the cross-track resolution ranges between $800 \mathrm{~m}$ to $1100 \mathrm{~m}$. 
Table 2. Data record properties

\begin{tabular}{lc}
\hline Parameter & Value \\
\hline Covered area & $25000 \mathrm{~km}^{2}$ \\
Total profile distance & $7494 \mathrm{~km}$ \\
Along-track resolution & $\sim 27-30 \mathrm{~m}^{(\text {qlook })} / \sim 15 \mathrm{~m}^{\left(S A R_{1}\right)} / \sim 3 \mathrm{~m}^{\left(S A R_{2}\right)}$ \\
Range resolution & $4.31 \mathrm{~m}$ \\
Data amount & $4.5 \mathrm{~GB}{ }^{(q l o o k)} / 9.5 \mathrm{~GB}{ }^{\left(S A R_{1}\right)} / 25.6 \mathrm{~GB}^{\left(S A R_{2}\right)}$ \\
\hline
\end{tabular}

\section{Results}

The design of the EGRIP-NOR-2018 radar survey enables a detailed analysis of the bed and englacial stratigraphy: (i) along radar profiles which are parallel to the ice flow (Figure 1c) and (ii) along radar profiles perpendicular to the ice flow, crossing the shear margins (Figure 1b). In addition, several radar lines cover the location where the northern shear margin shifts its location (Figure 1a) and an area South-West of EastGRIP where we observe patterns of strong internal ice deformation (location indicated in Figure 1a).

In flow-parallel profiles, we observe three regimes showing different characteristics in the radar stratigraphy. Figure 2 shows a $200 \mathrm{~km}$ long flow-parallel radargram extending from the far upstream end outside of the NEGIS up to $30 \mathrm{~km}$ downstream of EastGRIP. The area outside of the ice stream in a distance of 0-60 km shows slightly folded internal layers, which have no connection to the local basal topography. Steeply dipping internal layers are characterised by a decrease in reflectivity with depth. The part of the profile, which is crossing the shear zone (in $60-90 \mathrm{~km}$ distance) is characterised by tight folds in the internal layers, which extend almost up to the ice surface. The folds' apparent wavelength in profile direction depends on the intersection angle with respect to the shear margin orientation. Folds are tightest in profiles oriented $\sim 90^{\circ}$ to the shear margin fold axis. We observe the best resolution of internal layers inside the ice stream, particulary in the lower part of the ice column. All distortions in the internal stratigraphy inside the ice stream seem to be related to the underlying bed.

Radar profiles oriented perpendicular to ice flow show a strong imprint of NEGIS' dynamics. The most striking features are tight folds in the area of the shear margins. Bright stripes characterise them in the radargrams (e.g. Figure 3), which represent a loss in return power due to steeply inclined internal reflectors (Holschuh et al., 2014). The onset of this kind of folding starts at the shear zone's outer boundary (marked by yellow triangles in Figure $3 \mathrm{c}$ and d). Depending on the ice stream's location and width, these folds can be traced towards the ice stream centre for up to tens of kilometres, also towards locations where no shearing at the ice surface is observed. This becomes evident by comparing the upstream and further downstream radargram in Figure $3 \mathrm{c}$ and $\mathrm{d}$.

At several locations in flow-perpendicular radargrams we observe a drawdown of the radar stratigraphy towards the shear zone's outer margin (see Figure 3c). In general, the stratigraphy of internal layers North-West of the NEGIS differs from the stratigraphy South-East of the NEGIS. The North-West is much more undisturbed than the South-East. A distinct example is shown in Figure $3 a$ and $b$. The stratigraphy is marked by long-wavelength anticlines and synclines with elevation differences 


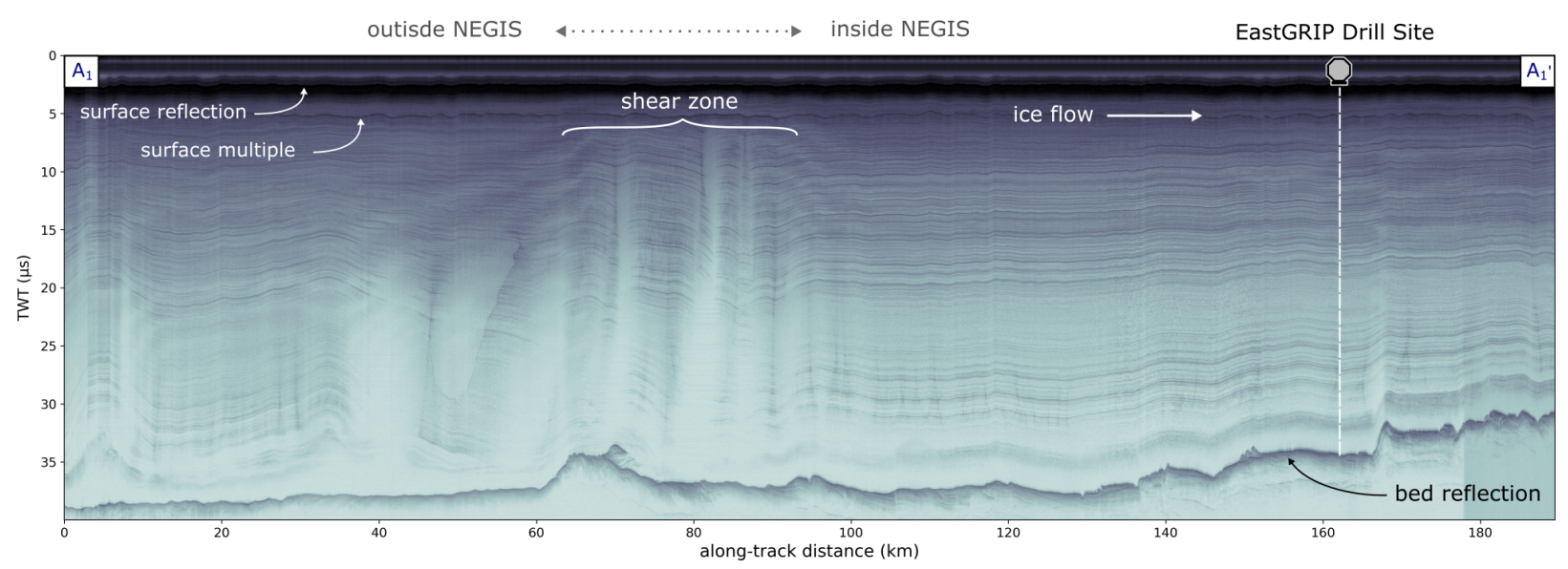

Figure 2. Flow-parallel radar profile $A$ composed of three frames: 20180512_01_001-004. The location is indicated in Figure 1a and covers the area outside of the ice stream, the shear zone and the ice stream's trunk. The position of the EastGRIP drill site is labeled and indicated with a white dashed vertical line.

of almost half of the ice column. In the anticlines' cores, we find strong englacial reflections, which have been misinterpreted before as bedrock (Franke et al., 2020). We note that some of the englacial reflections appear to be attached to the basal reflection (Figure 3a). Figure 3b shows that the deformations patterns in the anticline cores are very complex.

\subsection{Data products}

We offer three different data products of the EGRIP-NOR-2018 radar survey: (i) quick-looks (qlook), (ii) SAR focused (SAR 1 ) and (iii) SAR focused with a large aperture $\left(\mathrm{SAR}_{2}\right)$. The general data record properties are shown in Table 2 and detailed documentation can be found in the CReSIS MCoRDS documentation (https://data.cresis.ku.edu/) and on the CReSIS Wiki Website (https://ops.cresis.ku.edu/wiki/index.php/Main_Page). In Figure 4 we provide an overview of the differences between these three data products of the radargrams.

\subsection{1 qlook}

This product uses unfocused synthetic aperture radar processing for each channel and assumes that all reflections arrive at the receiver from nadir. The data are coherently stacked in slow time and no correction for propagation delay changes is applied. Here, no motion compensation is applied. Finally, the signals from all eight channels are averaged incoherently. The range resolution is the same as for all other products. The trace spacing is $\sim 27-30 \mathrm{~m}$.

\subsubsection{SAR with default settings $\left(\mathrm{SAR}_{1}\right)$}

This data product uses focused synthetic aperture radar processing (fk migration) on each channel individually. The SAR processing requires a uniformly sampled linear trajectory along the extent of the SAR aperture. Motion compensation is applied 

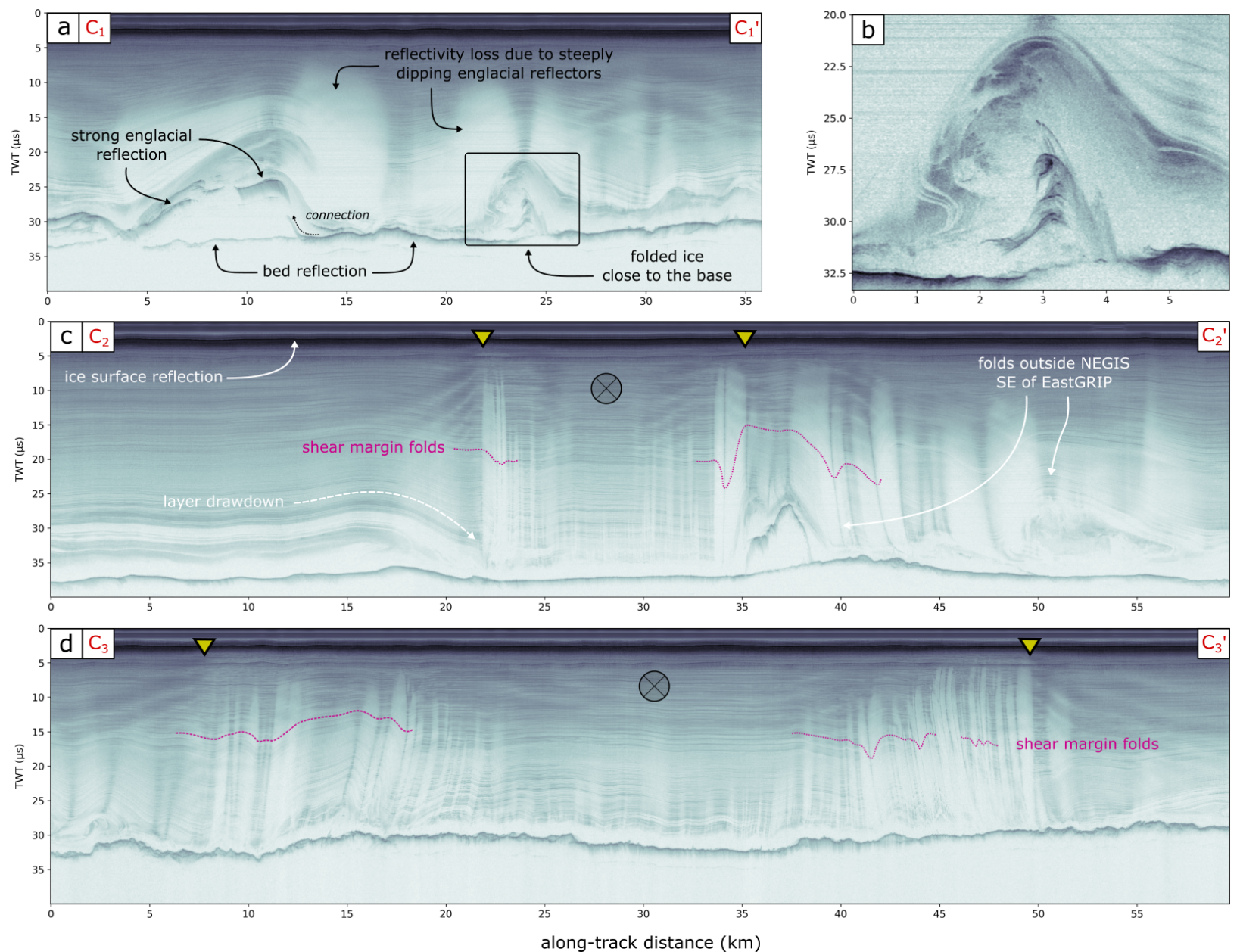

Figure 3. Radar profiles $C_{1,2,3}$ (frames 20180508_06_003, 20180511_01_007 and 20180514_01_011-012, respectively). The corresponding locations are shown in Figure 1a. Panel (a) shows a profile located outside of the NEGIS, SE of EastGRIP. A close up of an anticline and other patterns of deformation are shown in panel (b), resembling the skeleton of a dead penguin. A slice through the ice stream in the upstream region is shown in panel (c) and a radar section further downstream in (d). The position of the shear margins (the maximum in the surface velocity gradient) are indicated with a yellow triangle and the folds in the shear margin areas with purple lines. The ice flow direction is out of the page. 

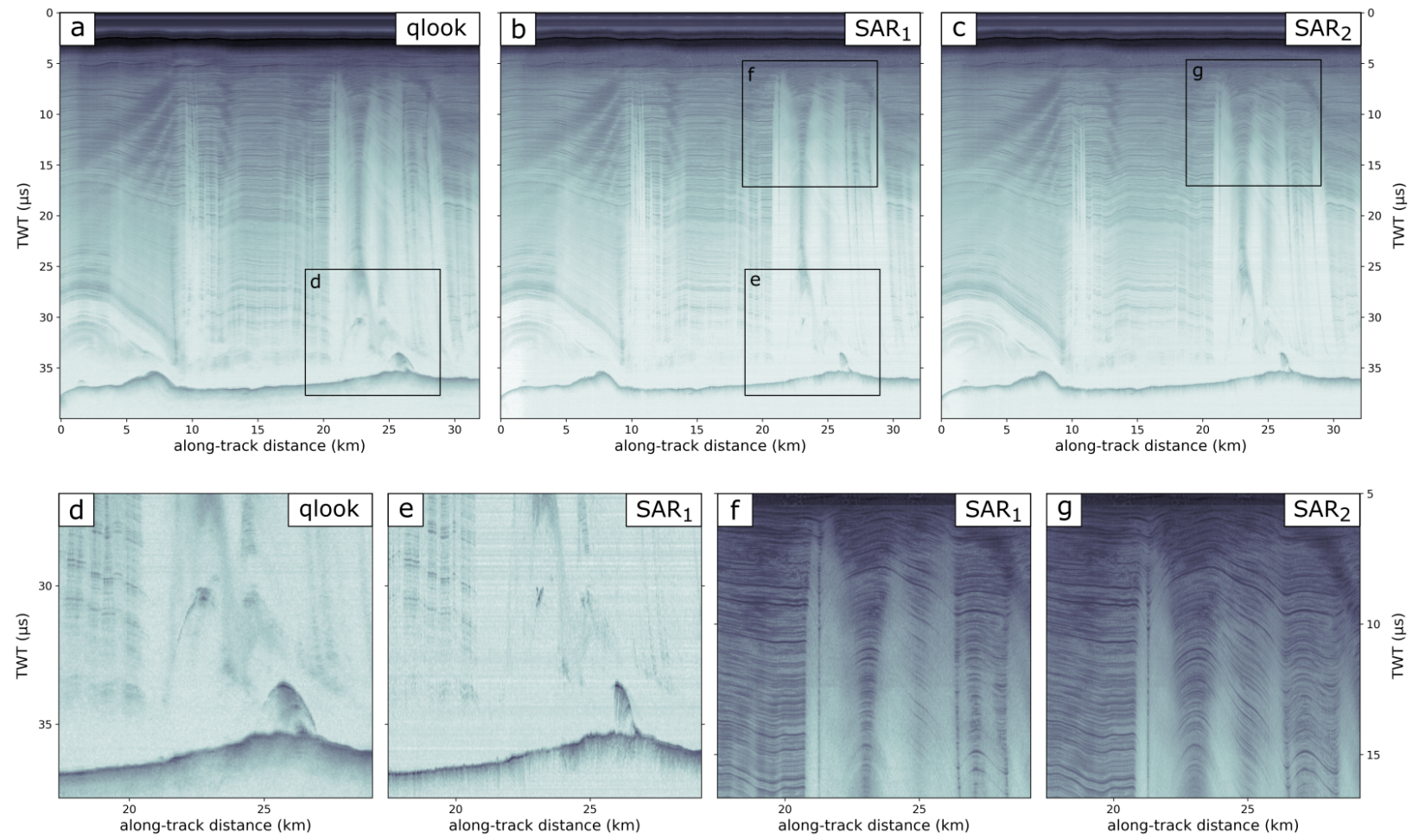

Figure 4. Radargrams of a flow-perpendicular radar profile showing the three different data products: (a) quick-look (qlook) processed, (b) SAR focused $\left(\mathrm{SAR}_{1}\right)$ and (c) SAR focused with a larger aperture $\left(\mathrm{SAR}_{2}\right)$. The main difference between qlook and $\mathrm{SAR}_{1}$ is the focusing of signals via fk migration (panel $\mathrm{d}$ and e). In contrast do the default SAR focusing (panel $\mathrm{f}$ ) a larger aperture enables a better resolution of steeply inclined internal layers (panel g).

using high precision processed GPS and INS data from the aircraft. The direction of arrival is estimated by delay-and-sum beamforming to combine the channels. A Hanning window is applied in the frequency domain to suppress sidelobes. This product is comparable to the CReSIS standard data product. The trace spacing is $\sim 15 \mathrm{~m}$.

\subsubsection{SAR with wider angular range $\left(\mathrm{SAR}_{2}\right)$}

By processing at a finer SAR resolution, the SAR processor uses scattered energy from a wider angular range around nadir to form the image. Since the angle of scattered returns from a specular internal layer is proportional to the internal layer slope, the SAR processor's increased sensitivity to larger angle returns translates to an increased sensitivity to layers with larger slopes. We achieve a better resolution of steeply inclined internal reflectors by changing the along-track resolution before SAR processing to $1 \mathrm{~m}\left(\approx \sigma_{x}=1\right.$, whereas the default setting is $\left.\sigma_{x}=2.5\right) .1 \mathrm{~m}$ is not the smallest possible value for processing, but is on the limit to achieve a sufficiently high SNR. The SNR is smaller for larger angles because the range to the target increases 
for greater angles, which leads to additional signal loss (spherical spreading loss and additional signal attenuation in ice). The differences between radargrams processed with $\sigma_{x}=1$ and 2.5 are shown in Figure 4 . The final trace spacing is $\sim 3 \mathrm{~m}$.

\subsubsection{Individual waveforms}

The combination of the three waveform images will increase the dynamic range of the whole radargram. However, specific analyses may require only a single waveform. Therefore, we provide the respective echogram data for each waveform separately (see Figure 5). The files are labelled with img_01, img_02 and img_03 for image 1, 2 and 3, respectively.
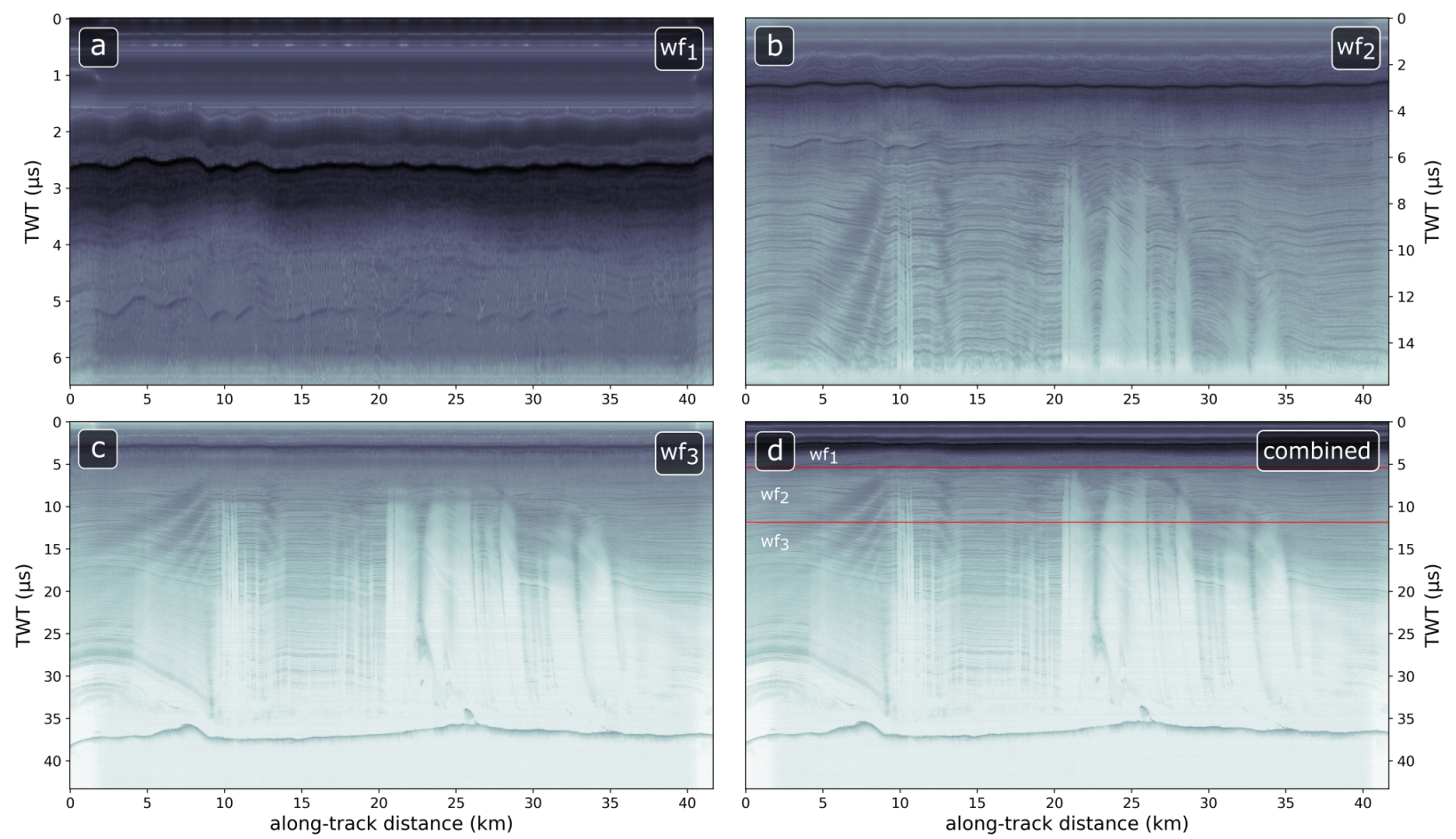

Figure 5. Radargrams of the frame 20180517_01_008 subdivided into (a) waveform 1, (b) waveform 2, (c) waveform 3 and (d) the radargram composed of all three waveforms in combination. The locations, where the different waveforms are concatenated, are indicated with red lines in (d). Waveform 1 and 2 are plotted at full range. Note the different resolution of the near-surface stratigraphy in waveforms 1 to 3.

\subsubsection{Image mode flights}

In addition to the data recorded in the so-called sounding mode, the data set also contains two segments (20180510_02 and 20180515_01) recorded in the image mode (see Table A1). The acquisition settings of these segments are slightly different since the transmission signals are composed of four instead of three pulses: $1 \mu$ s and $3 \mu$ s waveforms with nadir directed transmit beam followed by two $10 \mu$ s waveforms, one with the transmit beam directed to the left and one with it directed to the right to increase the imaged swath width at the ice bottom. We processed the data in a way that the $10 \mu \mathrm{s}$ left and $10 \mu \mathrm{s}$ right 
https://doi.org/10.5194/essd-2021-91

Preprint. Discussion started: 6 April 2021

(c) Author(s) 2021. CC BY 4.0 License.

(c) (i)

signal are steered towards nadir during data processing. This is possible because both waveforms contain nadir information since the beams overlap at nadir. However, the reflection power from nadir is reduced because the two side looking transmit beams have reduced gain by about 3-4 $\mathrm{dB}$ relative to when the beam is pointed directly at nadir. The third waveform (see Figure $5 \mathrm{c}$ and d) in the combined image for the two particular segments has been computed from the coherent combination of both, the $10 \mu$ s left and $10 \mu$ s right return signals.

\subsection{Data formats}

We provide the main radar data and auxiliary data in the following formats:

1. The radar data containing a matrix of the echogram and the corresponding GPS information, such as coordinates, aircraft elevation, and timing of every trace, are stored as matfiles (HDF-5 based format). The echograms are provided for the combined waveform product as well as for the individual waveforms. Furthermore, these files contain cell arrays with information about all processing parameters used.

2. A set of figures for each profile, showing the radargram and its respective location in the EGRIP-NOR-2018 survey.

3. A set of shapefiles (lines) containing the location of every frame.

4. An Excel Spreadsheet which contains all parameter settings applied during radar data processing.

In the Appendix we describe the data architecture and how the data is stored in the PANGAEA repository.

\section{Relevance of the data set}

This radar data set provides essential observations of internal and bed reflections to determine spatial distribution of ice thickness, internal layering and reflectivity. These observables constitute boundary conditions and elucidate properties and processes of the NEGIS. The data comprises $\sim 7500 \mathrm{~km}$ high-resolution radar data to the scientific community. In contrast to previous surveys in this area, the data presented here were specifically recorded over a broad spatial extent to understand the history of the NEGIS and our general understanding about ice streams. The tightly spaced radar profiles perpendicular to ice flow allow a 3D interpretation of the ice-internal stratigraphic architecture. Because most radar lines are directly or indirectly spatially connected to the location of the drill site of the EastGRIP ice core, these data are significant for various objectives regarding the ice-dynamic understanding of NEGIS as well as interpretation of the climate proxy record retrievable from the ice core. With this data set the scientific community will be able to upscale the findings of the EastGRIP project from the location of the ice core to the immediate surrounding of the upstream part of the NEGIS. The prospect that parts of the ice core can be rotated back into their correct geographic direction (Westhoff et al., 2020) also allows a systematic analysis of ice crystal orientation fabric together with the radar data. Furthermore, the data presented here can be combined with the radar data acquired during Operation Ice Bridge (OIB) to extend the large-scale understanding of glaciological properties in the Greenland Ice Sheet. 
https://doi.org/10.5194/essd-2021-91

Preprint. Discussion started: 6 April 2021

(c) Author(s) 2021. CC BY 4.0 License.

(c) (1)

We present a high-resolution ice-penetrating radar data set at the onset region of the NEGIS. The EGRIP-NOR-2018 radar data reveal the internal stratigraphy and bed topography of the upstream part of the NEGIS in high vertical and horizontal resolution, given the dense coverage. Several survey lines intersect at the EastGRIP drill site location, enabling a combination of both data sets. Ultimately, this data set will improve our understanding of the NEGIS in its present form and also contributes to our understanding of its genesis and evolution. Radar and auxiliary data will be provided as matfiles for the combined echograms as well as for the individual waveforms. The radar data products comprise unfocused data (qlook), SAR focused data $\left(\mathrm{SAR}_{1}\right)$ and SAR focused data with a wider angular range $\left(\mathrm{SAR}_{2}\right)$

\section{Code and data availability}

The EGRIP-NOR-2018 radar data products are available at the PANGAEA Data Publisher (https://doi.pangaea.de/10.1594/ PANGAEA.928569; Franke et al. 2021a). The EGRIP-NOR-2018 bed topography (Franke et al. (2019) is available under https://doi.pangaea.de/10.1594/PANGAEA.907918). The CReSIS-toolbox is available under https://github.com/CReSIS/ and the main documentation can be found at https://ops.cresis.ku.edu/wiki/. The MEaSUREs Greenland Ice Sheet Velocity Map from InSAR Data, Version 2 from Joughin et al. (2017) is available from https://doi.org/10.5067/OC7B04ZM9G6Q. 
https://doi.org/10.5194/essd-2021-91

Preprint. Discussion started: 6 April 2021

(c) Author(s) 2021. CC BY 4.0 License.

(c) (1)

\section{Appendix A: Additional Information for the Segments}

295 The data are stored in zip archives for each segment and processing product, respectively. For details on the specifications of each segment and their respective coverage, see Table A1 and Figure A1. The filenames of the archives are composed of the segment and the data product (e.g. 20180508_02_qlook.zip, 20180508_02_sar1.zip and 20180508_02_sar2.zip for the quick-look, $\mathrm{SAR}$ with default settings $\left(\mathrm{SAR}_{1}\right)$ and $\mathrm{SAR}$ with larger angular range data product $\left(\mathrm{SAR}_{2}\right)$, respectively). Each zip archive contains the individual frames in the matfile format.

\section{Table A1.}

\begin{tabular}{|c|c|c|c|c|}
\hline Segment & Frames & Frequency Range & Waveforms (pulse length and direction) & Segment Length \\
\hline 20180508_02 & 2 & $180-210 \mathrm{MHz}$ & $3(1 \mu \mathrm{s}, 3 \mu \mathrm{s}, 10 \mu \mathrm{s}$ nadir $)$ & $72 \mathrm{~km}$ \\
\hline 20180508_06 & 4 & $180-210 \mathrm{MHz}$ & $3(1 \mu \mathrm{s}, 3 \mu \mathrm{s}, 10 \mu \mathrm{s}$ nadir $)$ & $189 \mathrm{~km}$ \\
\hline 20180509_01 & 18 & $180-210 \mathrm{MHz}$ & $3(1 \mu \mathrm{s}, 3 \mu \mathrm{s}, 10 \mu \mathrm{s}$ nadir $)$ & $852 \mathrm{~km}$ \\
\hline 20180510_01 & 15 & $180-210 \mathrm{MHz}$ & $3(1 \mu \mathrm{s}, 3 \mu \mathrm{s}, 10 \mu \mathrm{s}$ nadir $)$ & $726 \mathrm{~km}$ \\
\hline 20180510_02 ${ }^{a}$ & 15 & $180-210 \mathrm{MHz}$ & $4(1 \mu \mathrm{s}$ and $3 \mu \mathrm{s}$ nadir, $10 \mu \mathrm{s}$ left, $10 \mu \mathrm{s}$ right $)$ & $675 \mathrm{~km}$ \\
\hline 20180511_01 & 13 & $180-210 \mathrm{MHz}$ & $3(1 \mu \mathrm{s}, 3 \mu \mathrm{s}, 10 \mu \mathrm{s}$ nadir $)$ & $721 \mathrm{~km}$ \\
\hline 20180512_01 & 15 & $180-210 \mathrm{MHz}$ & $3(1 \mu \mathrm{s}, 3 \mu \mathrm{s}, 10 \mu \mathrm{s}$ nadir $)$ & $635 \mathrm{~km}$ \\
\hline 20180512_02 & 14 & $180-210 \mathrm{MHz}$ & $3(1 \mu \mathrm{s}, 3 \mu \mathrm{s}, 10 \mu \mathrm{s}$ nadir $)$ & $645 \mathrm{~km}$ \\
\hline 20180514_01 & 19 & $180-210 \mathrm{MHz}$ & $3(1 \mu \mathrm{s}, 3 \mu \mathrm{s}, 10 \mu \mathrm{s}$ nadir $)$ & $750 \mathrm{~km}$ \\
\hline 20180514_03 & 12 & $180-210 \mathrm{MHz}$ & $3(1 \mu \mathrm{s}, 3 \mu \mathrm{s}, 10 \mu \mathrm{s}$ nadir $)$ & $740 \mathrm{~km}$ \\
\hline 20180515_01 ${ }^{a}$ & 16 & $180-210 \mathrm{MHz}$ & $4(1 \mu \mathrm{s}$ and $3 \mu \mathrm{s}$ nadir, $10 \mu \mathrm{s}$ left, $10 \mu \mathrm{s}$ right $)$ & $733 \mathrm{~km}$ \\
\hline 20180517_01 & 20 & $180-210 \mathrm{MHz}$ & $3(1 \mu \mathrm{s}, 3 \mu \mathrm{s}, 10 \mu \mathrm{s}$ nadir $)$ & $753 \mathrm{~km}$ \\
\hline
\end{tabular}

${ }^{a}$ The nadir part of all four waveforms was used for image combination 

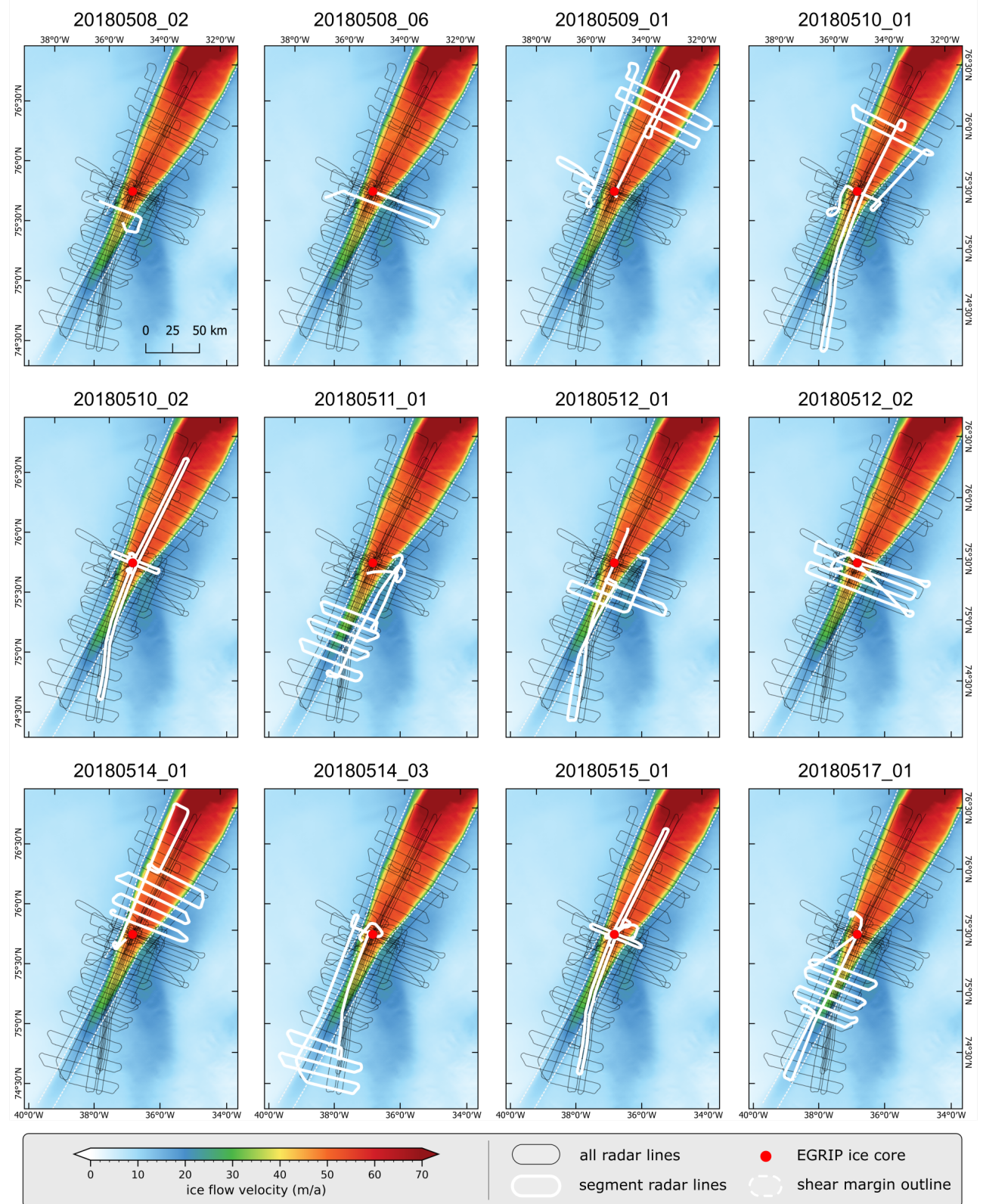

all radar lines

segment radar lines

- EGRIP ice core shear margin outline

Figure A1. Radar profiles locations of the 12 segments shown in Table A1 of the EGRIP-NOR-2018 data set. The respective segments are highlighted with a white line and the radar profiles of the complete survey with a finer black line. The background map represents ice surface velocity from Joughin et al. (2017). The shear margin is indicated with a white dashed outline and the location of EastGRIP with a red dot. 
https://doi.org/10.5194/essd-2021-91

Preprint. Discussion started: 6 April 2021

(c) Author(s) 2021. CC BY 4.0 License.

(c) (1)

300 Author contributions. Steven Franke, Nils Dörr and Tamara Gerber wrote the manuscript. Tobias Binder, Daniela Jansen and John Paden acquired the radar data in the field. Olaf Eisen and Daniela Jansen were PI and co-PI of the radar campaign. Tobias Binder and Steven Franke processed the radar data with the support of John Paden, Daniela Jansen, Veit Helm and Daniel Steinhage. All authors discussed and revised the manuscript.

Competing interests. The authors declare that they have no conflict of interest.

305 Acknowledgements. We thank the AWI and Ken Borek crew of the research aircraft Polar6. Logistical support in the field was provided by the East Greenland Ice-Core Project. EastGRIP is directed and organized by the centre of Ice and Climate at the Niels Bohr Institute. It is supported by funding agencies and institutions in Denmark (A. P. Møller Foundation, University of Copenhagen), USA (U.S. National Science Foundation, Office of Polar Programs), Germany (Alfred Wegener Institute, Helmholtz Centre for Polar and Marine Research), Japan (National Institute of Polar Research and Arctic Challenge for Sustainability), Norway (University of Bergen and Bergen Research

310 Foundation), Switzerland (Swiss National Science Foundation), France (French Polar Institute Paul-Emile Victor, Institute for Geosciences and Environmental research) and China (Chinese Academy of Sciences and Beijing Normal University). We acknowledge the use of the CReSIS toolbox from CReSIS generated with support from the University of Kansas, NASA Operation IceBridge grant NNX16AH54G, and NSF grants ACI-1443054, OPP-1739003, and IIS-1838230. 
https://doi.org/10.5194/essd-2021-91

Preprint. Discussion started: 6 April 2021

(c) Author(s) 2021. CC BY 4.0 License.

(c) (i)

\section{References}

Allen, C. T., Mozaffar, S. N., and Akins, T. L.: Suppressing coherent noise in radar applications with long dwell times, IEEE Geoscience and Remote Sensing Letters, 2, 284-286, https://doi.org/10.1109/LGRS.2005.847931, 2005.

Baldwin, D. J., Bamber, J. L., Payne, A. J., and Layberry, R. L.: Using internal layers from the Greenland ice sheet, identified from radio-echo sounding data, with numerical models, Annals of Glaciology, 37, 325-330, https://doi.org/10.3189/172756403781815438, 2003.

Bamber, J. L., Griggs, J. A., Hurkmans, R. T., Dowdeswell, J. A., Gogineni, S. P., Howat, I., Mouginot, J., Paden, J., Palmer, S., Rignot, E., and Steinhage, D.: A new bed elevation dataset for Greenland, Cryosphere, 7, 499-510, https://doi.org/10.5194/tc-7-499-2013, 2013.

Blackwell, D. and Richards, M.: Geothermal Map of North America, AAPG Map, scale 1:6,500,000, 2004.

Bohleber, P., Wagner, N., and Eisen, O.: Permittivity of ice at radio frequencies: Part II. Artificial and natural polycrystalline ice, Cold Regions Science and Technology, 83-84, 13-19, https://doi.org/https://doi.org/10.1016/j.coldregions.2012.05.010, https://www.sciencedirect.com/ science/article/pii/S0165232X12001103, 2012.

Bons, P. D., de Riese, T., Franke, S., Llorens, M.-G., Sachau, T., Stoll, N., Weikusat, I., and Zhang, Y.: Comment on "Exceptionally high heat flux needed to sustain the Northeast Greenland Ice Stream” by S. Smith-Johnson et al., The Cryosphere, 14, 841-854, 2020, The Cryosphere Discussions, 2020, 1-5, https://doi.org/10.5194/tc-2020-339, https://tc.copernicus.org/preprints/tc-2020-339/, 2020.

Buchardt, S. L. and Dahl-Jensen, D.: Estimating the basal melt rate at NorthGRIP using a Monte Carlo technique, Annals of Glaciology, 45, 137-142, https://doi.org/10.3189/172756407782282435, 2007.

Carter, S. P., Blankenship, D. D., Peters, M. E., Young, D. A., Holt, J. W., and Morse, D. L.: Radar-based subglacial lake classification in Antarctica, Geochemistry, Geophysics, Geosystems, 8, https://doi.org/10.1029/2006GC001408, 2007.

Christianson, K., Peters, L. E., Alley, R. B., Anandakrishnan, S., Jacobel, R. W., Riverman, K. L., Muto, A., and Keisling, B. A.: Dilatant till facilitates ice-stream flow in northeast Greenland, Earth and Planetary Science Letters, 401, 57-69, https://doi.org/10.1016/j.eps1.2014.05.060, https://doi.org/10.1016\%2Fj.eps1.2014.05.060, 2014.

Copland, L. and Sharp, M.: Mapping thermal and hydrological conditions beneath a polythermal glacier with radio-echo sounding, Journal of Glaciology, 47, 232-242, https://doi.org/10.3189/172756501781832377, 2001.

CReSIS: CReSIS rds documentation., https://data.cresis.ku.edu/data/rds/rds_readme.pdf, 2020a.

CReSIS: CReSIS Toolbox [computer software], Lawrence, Kansas, USA. Retrieved from https://github.com/CReSIS/., https://ops.cresis.ku. edu/wiki/index.php/Main_Page, 2020b.

Dahl-Jensen, D., Thorsteinsson, T., Alley, R., and Shoji, H.: Flow properties of the ice from the Greenland Ice Core Project ice core: The reason for folds?, Journal of Geophysical Research: Oceans, 102, 26 831-26 840, https://doi.org/10.1029/97JC01266, 1997.

Eder, K., Reidler, C., Mayer, C., and Leopold, M.: Crevasse detection in alpine areas using ground penetrating radar as a component for a mountain guide system, International Archives of the Photogrammetry, Remote Sensing and Spatial Information Sciences - ISPRS Archives, 37, 837-842, 2008.

Eisen, O., Hamann, I., Kipfstuhl, S., Steinhage, D., and Wilhelms, F.: Direct evidence for continuous radar reflector originating from changes in crystal-orientation fabric, Cryosphere, 1, 1-10, https://doi.org/10.5194/tc-1-1-2007, 2007.

Fahnestock, M., Bindschadler, R., Kwok, R., and Jezek, K.: Greenland Ice Sheet surface properties and ice dynamics from ERS-1 SAR imagery, https://doi.org/10.1126/science.262.5139.1530, 1993. 
https://doi.org/10.5194/essd-2021-91

Preprint. Discussion started: 6 April 2021

(c) Author(s) 2021. CC BY 4.0 License.

(c) (i)

Fahnestock, M. A., Joughin, I., Scambos, T. A., Kwok, R., Krabill, W. B., and Gogineni, S.: Ice-stream-related patterns of ice flow in the interior of northeast Greenland, Journal of Geophysical Research Atmospheres, 106, 34 035-34 045, https://doi.org/10.1029/2001JD900194, 2001.

Franke, S., Jansen, D., Binder, T., Dörr, N., Paden, J., Helm, V., Steinhage, D., and Eisen, O.: Bedrock topography and ice thickness in the onset region of the Northeast Greenland Ice Stream recorded with the airborne AWI Ultra-Wideband radar (UWB) in 2018 [DATASET], https://doi.org/10.1594/PANGAEA.907918, 2019.

Franke, S., Jansen, D., Binder, T., Dörr, N., Helm, V., Paden, J., Steinhage, D., and Eisen, O.: Bed topography and subglacial landforms in the onset region of the Northeast Greenland Ice Stream, Annals of Glaciology, 61, 143-153, https://doi.org/10.1017/aog.2020.12, 2020.

Franke, S., Binder, T., Jansen, D., Paden, J. D., Dörr, N., Gerber, T., Miller, H., Dahl-Jensen, D., Helm, V., Steinhage, D., Weikusat, I., Wilhelms, F., and Eisen, O.: [DATASET] Ultra-wideband radar data over the shear margins and along flow lines at the onset region of the Northeast Greenland Ice Stream (NEGIS), https://doi.pangaea.de/10.1594/PANGAEA.928569, 2021a.

Franke, S., Jansen, D., Beyer, S., Neckel, N., Binder, T., Paden, J., and Eisen, O.: Complex Basal Conditions and Their Influence on Ice Flow at the Onset of the Northeast Greenland Ice Stream, Journal of Geophysical Research: Earth Surface, 126, e2020JF005 689, https://doi.org/10.1029/2020JF005689, https://agupubs.onlinelibrary.wiley.com/doi/abs/10.1029/2020JF005689, 2021 b.

Frezzotti, M., Gandolfi, S., and Urbini, S.: Snow megadunes in Antarctica: Sedimentary structure and genesis, Journal of Geophysical Research Atmospheres, 107, ACL 1-1-ACL 1-12, https://doi.org/10.1029/2001JD000673, 2002.

Fujita, S., Maeno, H., Uratsuka, S., Furukawa, T., Mae, S., Fujii, Y., and Watanabe, O.: Nature of radio echo layering in the Antarctic ice sheet detected by a two-frequency experiment, Journal of Geophysical Research: Solid Earth, 104, 13013-13024, https://doi.org/10.1029/1999jb900034, 1999.

Gazdag, J.: Wave equation migration with the phase-shift method, Geophysics, 43, 1342-1351, https://doi.org/10.1190/1.1440899, https: //doi.org/10.1190/1.1440899, 1978.

Gerber, T. A., Hvidberg, C. S., Rasmussen, S. O., Franke, S., Sinnl, G., Grinsted, A., Jansen, D., and Dahl-Jensen, D.: Upstream flow effects revealed in the EastGRIP ice core using a Monte Carlo inversion of a two-dimensional ice-flow model, The Cryosphere Discussions, 2021, 1-32, https://doi.org/10.5194/tc-2021-63, https://tc.copernicus.org/preprints/tc-2021-63/, 2021.

Gogineni, S., Chuah, T., Allen, C., Jezek, K., and Moore, R. K.: An improved coherent radar depth sounder, Journal of Glaciology, 44, 659-669, https://doi.org/10.3189/S0022143000002161, 1998.

Hale, R., Miller, H., Gogineni, S., Yan, J. B., Rodriguez-Morales, F., Leuschen, C., Paden, J., Li, J., Binder, T., Steinhage, D., Gehrmann, M., and Braaten, D.: Multi-channel ultra-wideband radar sounder and imager, in: 2016 IEEE International Geoscience and Remote Sensing Symposium (IGARSS), pp. 2112-2115, https://doi.org/10.1109/IGARSS.2016.7729545, 2016.

Hempel, L. and Thyssen, F.: Deep radio echo soundings in the vicinity of GRIP and GISP2 drill sites, Greenland, Polarforschung, 62, 11-16, 1992.

Hempel, L., Thyssen, F., Gundestrup, N., Clausen, H. B., and Miller, H.: A comparison of radio-echo sounding data and electrical conductivity of the GRIP ice core, Journal of Glaciology, 46, 369-374, https://doi.org/10.3189/172756500781833070, 2000.

Hodgkins, R., Siegert, M. J., and Dowdeswell, J. A.: Geophysical investigations of ice-sheet internal layering and deformation in the Dome C region of central East Antarctica, Journal of Glaciology, 46, 161-166, https://doi.org/10.3189/172756500781833223, 2000.

Holschuh, N., Christianson, K., and Anandakrishnan, S.: Power loss in dipping internal reflectors, imaged using ice-penetrating radar, Annals of Glaciology, 55, 49-56, https://doi.org/10.3189/2014aog67a005, 2014. 
https://doi.org/10.5194/essd-2021-91

Preprint. Discussion started: 6 April 2021

(c) Author(s) 2021. CC BY 4.0 License.

(c) (i)

Holschuh, N., Lilien, D. A., and Christianson, K.: Thermal Weakening, Convergent Flow, and Vertical Heat Transport in the Northeast Greenland Ice Stream Shear Margins, Geophysical Research Letters, 46, 8184-8193, https://doi.org/10.1029/2019GL083436, https:// onlinelibrary.wiley.com/doi/abs/10.1029/2019GL083436, 2019.

Huybrechts, P., Steinhage, D., Wilhelms, F., and Bamber, J.: Balance velocities and measured properties of the Antarctic ice sheet from a new compilation of gridded data for modelling, Annals of Glaciology, 30, 52-60, https://doi.org/10.3189/172756400781820778, 2000.

Jacobel, R. W. and Hodge, S. M.: Radar internal layers from the Greenland Summit, Geophysical Research Letters, 22, 587-590, https://doi.org/10.1029/95GL00110, 1995.

Jacobel, R. W., Gades, A. M., Gottschling, D. L., Hodge, S. M., and Wright, D. L.: Interpretation of radar-detected internal layer folding in West Antarctic ice streams, Journal of Glaciology, 39, 528-537, https://doi.org/10.1017/s0022143000016427, 1993.

Jóhannesson, T., Pálmason, B., Hjartarson, A., Jarosch, A. H., Magnússon, E., Belart, J. M. C., and Gudmundsson, M. T.: Non-surface mass balance of glaciers in Iceland, Journal of Glaciology, 66, 685-697, https://doi.org/10.1017/jog.2020.37, 2020.

Jordan, T. M., Schroeder, D. M., Elsworth, C. W., and Siegfried, M. R.: Estimation of ice fabric within Whillans Ice Stream using polarimetric phase-sensitive radar sounding, Annals of Glaciology, 61, 74-83, https://doi.org/10.1017/aog.2020.6, 2020.

Joughin, I., Fahnestock, M., MacAyeal, D., Bamber, J. L., and Gogineni, P.: Observation and analysis of ice flow in the largest Greenland ice stream, Journal of Geophysical Research Atmospheres, 106, 34 021-34 034, https://doi.org/10.1029/2001JD900087, 2001.

Joughin, I., Smith, B. E., and Howat, I. M.: A complete map of Greenland ice velocity derived from satellite data collected over 20 years, Journal of Glaciology, 64, 1-11, https://doi.org/10.1017/jog.2017.73, 2017.

Kanagaratnam, P., Gogineni, S. P., Gundestrup, N., and Larsen, L.: High-resolution radar mapping of internal layers at the North Greenland Ice Core Project, Journal of Geophysical Research Atmospheres, 106, 33 799-33 811, https://doi.org/10.1029/2001JD900191, 2001.

Keisling, B. A., Christianson, K., Alley, R. B., Peters, L. E., Christian, J. E., Anandakrishnan, S., Riverman, K. L., Muto, A., and Jacobel, R. W.: Basal conditions and ice dynamics inferred from radar-derived internal stratigraphy of the northeast Greenland ice stream, Annals of Glaciology, 55, 127-137, https://doi.org/10.3189/2014AoG67A090, 2014.

Leuschen, C., Gogineni, S., and Tammana, D.: SAR processing of radar echo sounder data, in: IGARSS 2000. IEEE 2000 International Geoscience and Remote Sensing Symposium. Taking the Pulse of the Planet: The Role of Remote Sensing in Managing the Environment. Proceedings (Cat. No.00CH37120), vol. 6, pp. 2570-2572, https://doi.org/10.1109/IGARSS.2000.859643, 2000.

Li, J., Paden, J., Leuschen, C., Rodriguez-Morales, F., Hale, R. D., Arnold, E. J., Crowe, R., Gomez-Garcia, D., and Gogineni, P.: HighAltitude Radar Measurements of Ice Thickness Over the Antarctic and Greenland Ice Sheets as a Part of Operation IceBridge, IEEE Transactions on Geoscience and Remote Sensing, 51, 742-754, https://doi.org/10.1109/TGRS.2012.2203822, 2013.

MacGregor, J. A., Fahnestock, M. A., Catania, G. A., Aschwanden, A., Clow, G. D., Colgan, W. T., Gogineni, S. P., Morlighem, M., Nowicki, S. M., Paden, J. D., Price, S. F., and Seroussi, H.: A synthesis of the basal thermal state of the Greenland Ice Sheet, Journal of Geophysical Research: Earth Surface, 121, 1328-1350, https://doi.org/10.1002/2015JF003803, 2016.

Matsuoka, K., Furukawa, T., Fujita, S., Maeno, H., Uratsuka, S., Naruse, R., and Watanabe, O.: Crystal orientation fabrics within the Antarctic ice sheet revealed by a multipolarization plane and dual-frequency radar survey, Journal of Geophysical Research: Solid Earth, 108, https://doi.org/10.1029/2003jb002425, 2003.

Millar, D. H.: Radio-echo layering in polar ice sheets and past volcanic activity, Nature, 292, 441-443, https://doi.org/10.1038/292441a0, 1981. 
https://doi.org/10.5194/essd-2021-91

Preprint. Discussion started: 6 April 2021

(c) Author(s) 2021. CC BY 4.0 License.

(c) (i)

Mottram, R., Simonsen, S. B., Svendsen, S. H., Barletta, V. R., Sørensen, L. S., Nagler, T., Wuite, J., Groh, A., Horwath, M., Rosier, J., Solgaard, A., Hvidberg, C. S., and Forsberg, R.: An integrated view of greenland ice sheet mass changes based on models and satellite observations, Remote Sensing, 11, 1-26, https://doi.org/10.3390/rs11121407, 2019.

Murray, T., Stuart, G. W., Miller, P. J., Woodward, J., Smith, A. M., Porter, P. R., and Jiskoot, H.: Glacier surge propagation by thermal evolution at the bed, Journal of Geophysical Research: Solid Earth, 105, 13 491-13 507, https://doi.org/10.1029/2000jb900066, 2000.

Nereson, N. A. and Raymond, C. F.: The elevation history of ice streams and the spatial accumulation pattern along the Siple Coast of West Antarctica inferred from ground-based radar data from three inter-ice-stream ridges, Journal of Glaciology, 47, 303-313, https://doi.org/10.3189/172756501781832197, 2001.

Nereson, N. A., Raymond, C. F., Jacobel, R. W., and Waddington, E. D.: The accumulation pattern across Siple Dome, West Antarctica, inferred from radar-detected internal layers, Journal of Glaciology, 46, 75-87, https://doi.org/10.3189/172756500781833449, 2000.

Nixdorf, U. and Göktas, F.: Spatial depth distribution of the subglacial bed and internal layers in the ice around NGRIP, Greenland, derived with airborne RES, Journal of Applied Geophysics, 47, 175-182, https://doi.org/10.1016/S0926-9851(01)00062-3, 2001.

Pälli, A., Kohler, J. C., Isaksson, E., Moore, J. C., Pinglot, J. F., Pohjola, V. A., and Samuelsson, H.: Spatial and temporal variability of snow accumulation using ground-penetrating radar and ice cores on a Svalbard glacier, Journal of Glaciology, 48, 417-424, https://doi.org/10.3189/172756502781831205, 2002.

Palmer, S. J., Dowdeswell, J. A., Christoffersen, P., Young, D. A., Blankenship, D. D., Greenbaum, J. S., Benham, T., Bamber, J., and Siegert, M. J.: Greenland subglacial lakes detected by radar, Geophysical Research Letters, 40, 6154-6159, https://doi.org/10.1002/2013GL058383, 2013.

Richardson, C., Aarholt, E., Hamran, S.-E., Holmlund, P., and Isaksson, E.: Spatial distribution of snow in western Dronning Maud Land, East Antarctica, mapped by a ground-based snow radar, Journal of Geophysical Research, 102, 20 343-20 353, 1997.

Rignot, E. and Mouginot, J.: Ice flow in Greenland for the International Polar Year 2008-2009, Geophysical Research Letters, 39, https://doi.org/10.1029/2012GL051634, 2012.

Riverman, K. L., Alley, R. B., Anandakrishnan, S., Christianson, K., Holschuh, N. D., Medley, B., Muto, A., and Peters, L. E.: Enhanced Firn Densification in High-Accumulation Shear Margins of the NE Greenland Ice Stream, Journal of Geophysical Research: Earth Surface, 124, 365-382, https://doi.org/10.1029/2017JF004604, https://onlinelibrary.wiley.com/doi/abs/10.1029/2017JF004604, 2019a.

Riverman, K. L., Anandakrishnan, S., Alley, R. B., Holschuh, N., Dow, C. F., Muto, A., Parizek, B. R., Christianson, K., and Peters, L. E.: Wet subglacial bedforms of the NE Greenland Ice Stream shear margins, Annals of Glaciology, https://doi.org/10.1017/aog.2019.43, 2019b.

Schroeder, D. M., Bingham, R. G., Blankenship, D. D., Christianson, K., Eisen, O., Flowers, G. E., Karlsson, N. B., Koutnik, M. R., Paden, J. D., and Siegert, M. J.: Five decades of radioglaciology, Annals of Glaciology, https://doi.org/10.1017/aog.2020.11, 2020.

Shepherd, A., Ivins, E., Rignot, E., Smith, B., van den Broeke, M., Velicogna, I., Whitehouse, P., Briggs, K., Joughin, I., Krinner, G., Nowicki, S., Payne, T., Scambos, T., Schlegel, N., A, G., Agosta, C., Ahlstrøm, A., Babonis, G., Barletta, V. R., Bjørk, A. A., Blazquez, A., Bonin, J., Colgan, W., Csatho, B., Cullather, R., Engdahl, M. E., Felikson, D., Fettweis, X., Forsberg, R., Hogg, A. E., Gallee, H., Gardner, A., Gilbert, L., Gourmelen, N., Groh, A., Gunter, B., Hanna, E., Harig, C., Helm, V., Horvath, A., Horwath, M., Khan, S., Kjeldsen, K. K., Konrad, H., Langen, P. L., Lecavalier, B., Loomis, B., Luthcke, S., McMillan, M., Melini, D., Mernild, S., Mohajerani, Y., Moore, P., Mottram, R., Mouginot, J., Moyano, G., Muir, A., Nagler, T., Nield, G., Nilsson, J., Noël, B., Otosaka, I., Pattle, M. E., Peltier, W. R., Pie, N., Rietbroek, R., Rott, H., Sandberg Sørensen, L., Sasgen, I., Save, H., Scheuchl, B., Schrama, E., Schröder, L., Seo, K. W., Simonsen, S. B., Slater, T., Spada, G., Sutterley, T., Talpe, M., Tarasov, L., van de Berg, W. J., van der Wal, W., van Wessem, M., Vishwakarma, 
https://doi.org/10.5194/essd-2021-91

Preprint. Discussion started: 6 April 2021

(c) Author(s) 2021. CC BY 4.0 License.

B. D., Wiese, D., Wilton, D., Wagner, T., Wouters, B., and Wuite, J.: Mass balance of the Greenland Ice Sheet from 1992 to 2018 , Nature, 579, 233-239, https://doi.org/10.1038/s41586-019-1855-2, 2020.

Siegert, M. J. and Hodgkins, R.: A stratigraphic link across $1100 \mathrm{~km}$ of the antarctic ice sheet between the Vostok ice-core site and Titan Dome (near South Pole), Geophysical Research Letters, 27, 2133-2136, https://doi.org/10.1029/2000GL008479, 2000.

Siegert, M. J., Hodgkins, R., and Dowdeswell, J. A.: A chronology for the Dome C deep ice-core site through radio-echo layer correlation with the Vostok ice core, Antarctica, Geophysical Research Letters, 25, 1019-1022, https://doi.org/10.1029/98GL00718, 1998.

Smith-Johnsen, S., Schlegel, N.-J., de Fleurian, B., and Nisancioglu, K. H.: Sensitivity of the Northeast Greenland Ice Stream to Geothermal Heat, Journal of Geophysical Research: Earth Surface, 125, e2019JF005 252, https://doi.org/https://doi.org/10.1029/2019JF005252, https: //agupubs.onlinelibrary.wiley.com/doi/abs/10.1029/2019JF005252, 2020.

Steinhage, D., Nixdorf, U., Meyer, U., and Miller, H.: New maps of the ice thickness and subglacial topography in Dronning Maud Land, Antarctica, determined by means of airborne radio-echo sounding, Annals of Glaciology, 29, 267-272, https://doi.org/10.3189/172756499781821409, 1999.

Straneo, F., Sutherland, D. A., Holland, D., Gladish, C., Hamilton, G. S., Johnson, H. L., Rignot, E., Xu, Y., and Koppes, M.: Characteristics of ocean waters reaching Greenland's glaciers, Annals of Glaciology, 53, 202-210, https://doi.org/10.3189/2012AoG60A059, 2012.

Vallelonga, P., Christianson, K., Alley, R. B., Anandakrishnan, S., Christian, J. E., Dahl-Jensen, D., Gkinis, V., Holme, C., Jacobel, R. W., Karlsson, N. B., Keisling, B. A., Kipfstuhl, S., Kjær, H. A., Kristensen, M. E., Muto, A., Peters, L. E., Popp, T., Riverman, K. L., Svensson, A. M., Tibuleac, C., Vinther, B. M., Weng, Y., and Winstrup, M.: Initial results from geophysical surveys and shallow coring of the Northeast Greenland Ice Stream (NEGIS), Cryosphere, 8, 1275-1287, https://doi.org/10.5194/tc-8-1275-2014, 2014.

Vaughan, D. G., Corr, H. F., Doake, C. S., and Waddington, E. D.: Distortion of isochronous layers in ice revealed by ground-penetrating radar, Nature, 398, 323-326, https://doi.org/10.1038/18653, 1999.

Wang, Z., Gogineni, S., Rodriguez-Morales, F., Yan, J.-B., Paden, J., Leuschen, C. Hale, R. D., Li, J., Carabajal, L. C., Gomez-Garcia, D., Townley, B., Willer, R., Stearns, L., Child, S., and Braaten, D.: Multichannel Wideband Synthetic Aperture Radar for Ice Sheet Remote Sensing: Development and the First Deployment in Antarctica, IEEE Journal of Selected Topics in Applied Earth Observations and Remote Sensing, 9, 1-28, https://doi.org/10.1109/JSTARS.2015.2403611, 2015.

Westhoff, J., Stoll, N., Franke, S., Weikusat, I., Bons, P., Kerch, J., Jansen, D., Kipfstuhl, S., and Dahl-Jensen, D.: A stratigraphy-based method for reconstructing ice core orientation, Annals of Glaciology, p. 1-12, https://doi.org/10.1017/aog.2020.76, 2020.

Williams, R. M., Ray, L. E., Lever, J. H., and Burzynski, A. M.: Crevasse detection in ice sheets using ground penetrating radar and machine learning, IEEE Journal of Selected Topics in Applied Earth Observations and Remote Sensing, 7, 4836-4848, https://doi.org/10.1109/JSTARS.2014.2332872, 2014.

Yin, J., Overpeck, J. T., Griffies, S. M., Hu, A., Russell, J. L., and Stouffer, R. J.: Different magnitudes of projected subsurface ocean warming around Greenland and Antarctica, Nature Geoscience, 4, 524-528, https://doi.org/10.1038/nphys1189, http://dx.doi.org/10.1038/ nphys1189, 2011.

Young, D. A., Schroeder, D. M., Blankenship, D. D., Kempf, S. D., and Quartini, E.: The distribution of basal water between Antarctic subglacial lakes from radar sounding, Philosophical Transactions of the Royal Society A: Mathematical, Physical and Engineering Sciences, 374, https://doi.org/10.1098/rsta.2014.0297, 2016.

Zamora, R., Casassa, G., Rivera, A., Ordenes, F., Neira, G., Araya, L., Mella, R., and Bunster, C.: Crevasse detection in glaciers of southern Chile and Antarctica by means of ground penetrating radar, IAHS-AISH Publication, pp. 153-162, 2007. 
https://doi.org/10.5194/essd-2021-91

Preprint. Discussion started: 6 April 2021

(c) Author(s) 2021. CC BY 4.0 License.

(c) (1)

Zeising, O. and Humbert, A.: Indication of high basal melting at EastGRIP drill site on the Northeast Greenland Ice Stream, The Cryosphere Discussions, 2021, 1-15, https://doi.org/10.5194/tc-2021-37, https://tc.copernicus.org/preprints/tc-2021-37/, 2021. 